DOI: $10.21608 / z v j z .2017 .29249$.

\title{
The Protective Effect of Pomegranate Juice in Silver Nanoparticles Induced Hepatotoxicity in Mature Male Albino Mice
}

\author{
Amira A. Sallam, Mona M. Ahmed, Ali H.Abou Hadeed and Magdy F. Abou El-Fotoh* \\ Forensic Medicine and Toxicology Department, Faculty of Veterinary Medicine, Zagazig \\ University, Egypt
}

\begin{abstract}
Nano-silvers (AgNPs) are widely used in medical and consumer products thanks to their excellent antimicrobial and anti-carcinogenic effects. Sixty mature male albino mice were randomly distributed into six groups (ten per group). The first group was kept as negative control, the $2^{\text {nd }}$ one was injected with silver nanoparticles $78 \mathrm{mg} / \mathrm{kg} \mathrm{BW} \mathrm{I} / \mathrm{P}$ for 14 days, group 3 was given pomegranate $(20 \mathrm{ml} / \mathrm{kg} \mathrm{BW})$ orally for 28 days, in the fourth group pomegranate was administrated for 14 days, followed by AgNPs for another 14 days. The fifth one AgNPs were $\mathrm{I} / \mathrm{P}$ injected for 14 days, followed by pomegranate for another 14 days. The last group received AgNPs and pomegranate on the same time with the same doses and route of previous groups. The results revealed that pomegranate has a protective impact on AgNPs toxicity in all groups. These results were clarified the findings of AST, ALT, SOD, CAT, MDA and GPX. The protective and treatment effects of pomegranate in hepatotoxicity were evidenced by regeneration of hepatocyte and kupffur cells.
\end{abstract}

Keywords: Pomegranate Juice, Silver Nanoparticles, Hepatotoxicity, Male, Albino Mice

\section{Introduction}

Pomegranate is one of the most widely known traditional edible plants [1]. It is mentioned in the Islam holly book (Quran), the Bible, the Torah an the Babylonian Talmod as the "Food of Gods" symbolizing abundancefruition and successfulness [2]. The useful effects of pomegranate are related to extensive spectrum of phytochemicals such as tannins, alkalioids and dyes [3]. The polyphenols are the main class of phytochemical that found in pomegranate, including hydrolysable ellagitannins which concentrated in the outer compartment of the fruit and punicalagin anomers $\mathrm{A}$ and $\mathrm{B}$, that represent more than $50 \%$ of the free radical scavenger activity of pomegranate juice [4]. There is scanty information regarding the distribution, bioavailability, absorption and metabolism of main ingredients of pomegranate but probably they all have similar mechanisms [5]. Oxidative stress is indicated by the emission of reactive oxygen species (ROS) which implicated in oxidative damage to different macromolecules [6]. A lot of evidences owed several human disorders such as diabetes, ageing process, atherosclerosis, arthritis, neurodegenerative diseases and cancer to oxidative stress [7]. Recently, pomegranate has a great importance due to its potent antioxidant properties especially in fruit, Juice and peel extracts [8]. Nano-Silvers (AgNPs) display different chemical and electronic properties / reactivity than their bulk counter parts [9]. Moreover, their minuet size, make it easily break through into the cells where they can induced tremendous damage [10]. The shape of nano-material may also play a role in governing potential toxicity. In general, the needle shape nano materials are sever toxic than the round shape ones. Indeed, recent data has suggested that single walled silver nanotubes (rods) are more toxic than fullerenes (cylindrical) of comparable size [11]. The surface properties of nanoparticles can influence how they interact with proteins, resulting in different types of corona and biological effects [12]. The kupffer cells are the specific part of liver that detoxifying and clearing foreign materials from the circulation. Also, liver endothelial cells participate in scavenging waste products, including nanoparticles from the circulation [13].

The liver sinusoids consists of endothelial cells and basal lamina with the connection between sinusoidal lumen and Diss space facilitating toxicants easily reach to hepatocytes but $500 \mathrm{~nm}$ size particles may not.

In the normal status the body is endowed with antioxidant to overcome the oxidative 
damage, so when the extreme ROS induced by nanoparticles exposure, the antioxidant mechanism become overwhelmed as the increase antioxidant production act as a vital line of defense to protect the body from damage. The scarcity of literature that evaluating the benefit role of pomegranate in hepatic damage induced by nanoparticles exposure, urges us to do this experiment to investigate and through the light on the prophylactic and protective antioxidant role of pomegranate juice against silver nanoparticles hepato toxicity

\section{Materials and Methods}

\section{Chemicals}

Pomegranate molasses were purchase from local market in Zagazig city, Sharkia Province Egypt. However, AgNPs are colloidal form with yellow / grey / opal colored liquid, particle size $(33 \mathrm{~nm})$ total diameter with wave length (400 -410 nm), were purchased from the International Center of nanotechnology, Sadaat University, El Sadaat City- Monifya Province, Egypt.

\section{Experimental design}

Sixty male albino mice with (25-30 gm) body weight were brought from Laboratory Animal Center in National Institute Animal Health El Doki Cairo, Egypt. The animals were kept in specific cages with food and water ad-libtum. All treatments in this experiment were done in the line with the international acceptance guidelines for laboratory animal's care and animal rights. The sixty mice were divided after two weeks of acclimation into different six groups as in Table (1).

Table 1: Showing animals grouping and treatment.

\begin{tabular}{|c|c|c|c|}
\hline Group $\quad$ Treatment & Treatment & Rout & Duration \\
\hline$-\mathrm{v}$ Control & Saline & $\mathrm{I} / \mathrm{P}$ & 28 days \\
\hline +v Control AgNPs & AgNPs (78 mg/kg b.wt.) [15] & $\mathrm{I} / \mathrm{P}$ & 14 days \\
\hline +V Control pomegranate (P.J.) & Pomegranate Juice $20 \mathrm{ml} / \mathrm{kg}$ b.wt. [16] & Orally & 28 days \\
\hline (P.J. Then AgNPs) & $\begin{array}{l}1^{\text {st }} \text { P.J. dosed orally for } 14 \text { days } \\
2^{\text {nd }}-\text { then inject AgNPs I/P for } 14 \text { days }\end{array}$ & P.J. orally & 14 days \\
\hline \multirow[t]{2}{*}{$\left(\mathrm{Ag}^{1} \mathrm{NPs}+\mathrm{P}^{2} . \mathrm{J}.\right)$} & $\begin{array}{l}\text { AgNPs injected I/P for } 14 \text { days then P.J. } \\
\text { orally for } 14 \text { day }\end{array}$ & $\begin{array}{l}\text { AgNPs I/P } \\
\quad \mathrm{I} / \mathrm{P}\end{array}$ & $\begin{array}{c}\text { Then } 14 \text { days } \\
14 \text { days } \\
\text { Then }\end{array}$ \\
\hline & & orally & 14 days \\
\hline AgNPs + P.J. on time & $\begin{array}{l}\text { AgNPs injected I/P and P.J. dosed orally } \\
\text { on the same time }\end{array}$ & $\begin{array}{l}\text { AgNPs I/P P.J. } \\
\text { orally }\end{array}$ & $\begin{array}{l}14 \text { day on time } \\
\text { the both }\end{array}$ \\
\hline
\end{tabular}

\section{Blood sampling}

After twenty eight days, all mice were killed by cervical decapitation after light anesthesia with diethyl ether and the blood was collected into clean, non-heparinized tubes. The collected blood was centrifuged at $3500 \mathrm{rpm}$ for 15 minutes, and then obtained serum was stored at $-20{ }^{\circ} \mathrm{C}$ till some liver enzymes and antioxidant status .

\section{Histopathological observation of liver}

Regarding to pathological evaluation, the hepatic tissues were fixed in $10 \%$ phosphate - buffered neutral formalin, dehydrated in graded ethyl alcohol and immersed in paraffin. Thin sections $(4-5 \mu \mathrm{m})$ were cut and stain with $\mathrm{H} \& \mathrm{E}$ for photo microscopic assessment [14].

\section{Biochemical analysis}

Determination of the activities of aspartate aminotransferase (AST/ GOT) in serum using in vitro kit. AST was measured using spectrophotometer [17]. Also, the activities of alanine aminotransferase (ALT/ GPT) were measured in serum using commercial available kit following the guidelines of manufacturer's procedures [18]. 
The activity of superoxide dismutase (SOD) in serum of experimental rats using epinephrine method [19].Moreover, the activity of catalase (CAT) in serum was also detected [20]. Determination of malondialdehyde (MDA) concentration in serum which acts as a marker of lipid peroxidation[21]. Determination of glutathione peroxidase (GPX) activity in serum of rats using NADPH as a substrate [22].

\section{Statistical analysis}

The results were shown as means \pm S.E. All data were done with statistical package for social sciences (SPSS 17.0 for windows) according [23]. The results were analyzed using one way anova followed by Duncans [24] test for the comparison between each treatment in all groups. Statistical significance was set up at $P<0.05$.

\section{Results and Discussion}

Table 2: Some liver enzymes (AST/GOT) and (ALT/ GPT) activities in serum of albino mice administered silver nanoparticles (AgNPs) toxicity and pomegranate juice as protective and treatment.

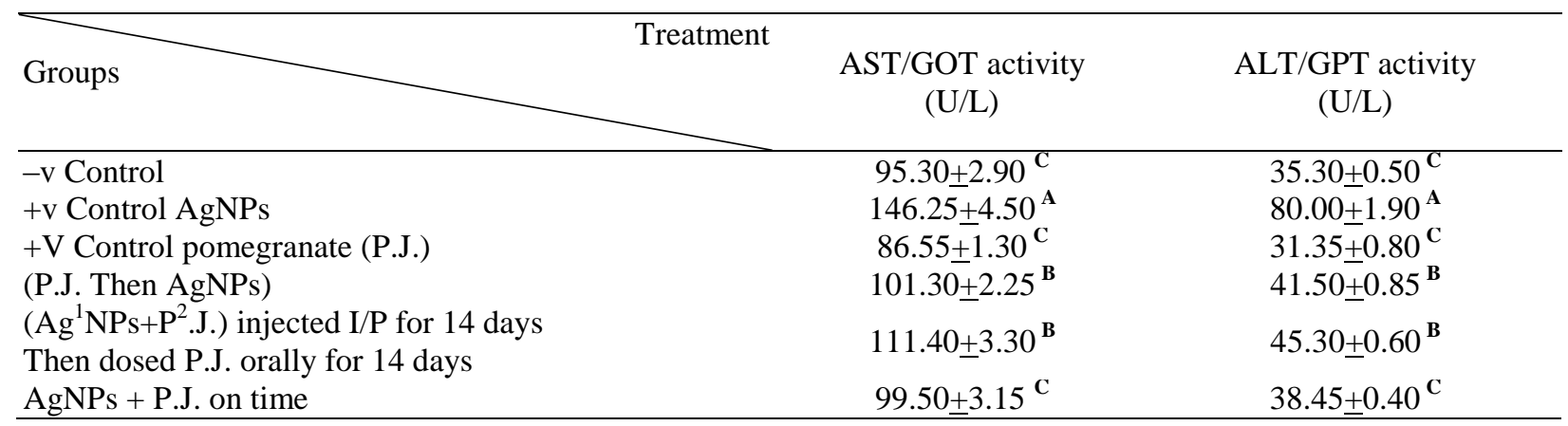

Mean within the same column carrying different superscripts are significant at $(P<0.05)$.

The results showed significant increase in GPX activity in AgNPs intoxicated mice and non-significant increase in groups treated with pomegranate as protective effect. Another finding which confirms the oxidative potential
In the last decades, nanotechnology has integrated in diverse consumer products with great effects on all parts of human, animals, environmental and industrial life. The use of nanoparticles (NPs) in industrial and medical devices has increases significantly recently, yet their biotoxic effects have not been studied extensively [25]. In our study, we detect hepato-toxicity by the predominant accumulation of AgNPs in the liver of male albino mice and evaluate the prophylactic role of pomegranate molasses as natural antioxidant.

Most significant difference in antioxidant enzymes was observed in all groups treated by AgNPs and remarkable the protective effects of pomegranate Juice treatment especially in group of dosed with P.J before AgNPs treatment. The obtained results were agreed with Ebabe et al., [26].

Table 3: Determination of superoxide dismutase (SOD) and catalase activities in serum of albino male mice administered AgNPs and pomegranate juice as protective and treatment

\begin{tabular}{|c|c|c|}
\hline Treatment & $\begin{array}{l}\text { Superoxide dismutase (SOD) } \\
\text { (U/L) }\end{array}$ & $\begin{array}{c}\text { Catalase enzyme (CAT) } \\
(\mathrm{U} / \mathrm{L})\end{array}$ \\
\hline -v Control & $15.65+0.35^{\mathrm{C}}$ & $55.25 \pm 0.55^{\mathrm{C}}$ \\
\hline +v Control AgNPs & $49.20+2.65^{\mathbf{A}}$ & $110.35 \pm 1.25^{\mathbf{A}}$ \\
\hline +V Control pomegranate (P.J.) & $14.10+0.15^{\mathrm{C}}$ & $53.50 \pm 0.60^{\mathrm{C}}$ \\
\hline (P.J. Then AgNPs) & $16.85 \pm 0.60^{\mathrm{C}}$ & $59.15 \pm 0.65^{\mathbf{B}}$ \\
\hline$\left(\mathrm{Ag}^{1} \mathrm{NPs}+\mathrm{P}^{2}\right.$.J.) injected $\mathrm{I} / \mathrm{P}$ for 14 days & $19.30 \pm 0.90^{\mathbf{B}}$ & $61.30 \pm 1.10^{\mathbf{B}}$ \\
\hline AgNPs + P.J. on time & $17.10 \pm 1.10^{\mathbf{B}}$ & $57.45 \pm 0.45^{\mathrm{C}}$ \\
\hline
\end{tabular}

Mean within the same column carrying different superscripts are significant at $(P<0.05)$. 
Table 4: Determination of Glutathione peroxidase (GPX) and malondialdhyde (MDA) concentration in serum of albino male mice administered AgNPs and pomegranate juice as protective and treatment.

\begin{tabular}{|c|c|c|}
\hline 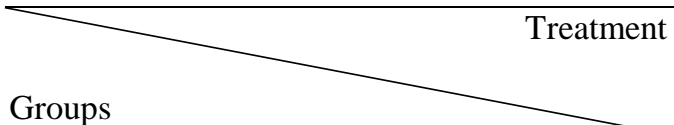 & $\begin{array}{l}\text { Glutathione peroxidase (GPX) } \\
(\mathrm{U} / \mathrm{L})\end{array}$ & $\begin{array}{l}\text { Malondialdhyde (MDA) } \\
\text { (U/L) }\end{array}$ \\
\hline$-\mathrm{v}$ Control & $23.60+0.15^{\mathrm{C}}$ & $44.45+0.44^{\mathrm{C}}$ \\
\hline +v Control AgNPs & $56.25 \pm 1.30^{\mathbf{A}}$ & $89.10 \pm 0.90^{\mathbf{A}}$ \\
\hline +V Control pomegranate (P.J.) & $21.75 \pm 0.30^{\mathrm{C}}$ & $42.25 \pm 0.35^{\mathrm{C}}$ \\
\hline (P.J. Then AgNPs) & $25.40 \pm 0.65^{\mathrm{C}}$ & $46.20 \pm 0.50^{\mathrm{C}}$ \\
\hline$\left(\mathrm{Ag}^{1} \mathrm{NPs}+\mathrm{P}^{2} . \mathrm{J}.\right)$ injected $\mathrm{I} / \mathrm{P}$ for 14 days & $27.30 \pm 0.10^{\mathbf{B}}$ & $49.65 \pm 0.60^{\text {B }}$ \\
\hline AgNPs + P.J. on time & $25.00 \pm 0.60^{\mathrm{C}}$ & $51.60 \pm 0.45^{\mathbf{B}}$ \\
\hline
\end{tabular}

Mean within the same column carrying different superscripts are significant at $(P<0.05)$.

Histopathological observation of albino male mice revealed no assent on the cytotoxicity of nano-sliver has been recorded; but, there is only a reduction in cells viability by toxicity due to the ability of liver to transformation of toxicant to other form which easily removed from the body [27]. As the liver was the main organ of detoxification, silver nanoparticles might have accumulated in it caused hepatic inflammation this is in consistent with Lee et al., [28] who reported mild infiltration of inflammatory cells around portal vein area of hepatocytes after silver nanoparticles administration in rat. The engulfment of AgNPs by macrophages (Kupffer cells), caused severe inflammation which indicated by elevation of some liver enzymes including, AST and ALT. In other words, silver nanoparticles administration increased both AST \& ALT activities in serum indicated hepatocellular damage. These were also confirmed by histopathological investigation which represents inflammatory cells infiltration in hepatocytes as reported by Gatti et al., [29]. But the groups treated firstly by P.J. then followed by silver nanoparticles or received both P.J. and silver nanoparticles on the same time were significantly improved than the group received firstly silver nanoparticles only due to P.J. has polyphenolic contents as ellagic acids that scavenging free radicals by electron donor antioxidant properties[4].
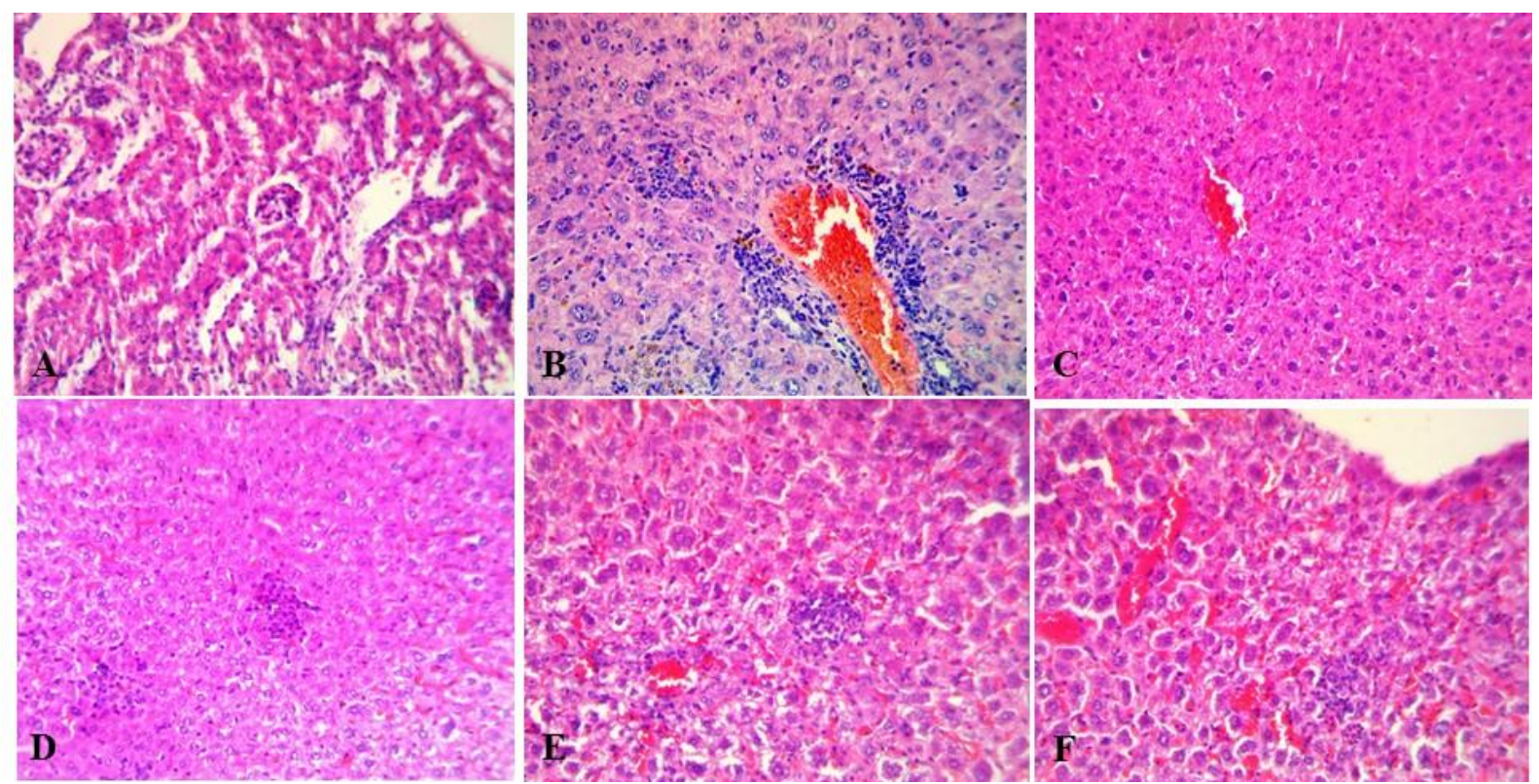

Figure 1 A. Liver of mice group (control) showing normal histological structure. (The hepatic lobule is roughly hexagonal shaped, with the sinusoids converging from the periphery to the central vein and the portal canals are present at approximately three of the six angles of the lobule. The hepatic parenchyma between the portal canals consists of cells arranged in cell plates), H\&E, $X$ 400. B. Liver of mice group (2), showing vascular congestion, parenchymal and 
perivascular mononuclear cell aggregation besides proliferated Von Kupfer cells, H\&E, X 400. C. Liver of mice group (3), showing normal histological structure with increase mitotic activity and numbers of Von Kupffer cells, H\&E, X 400. D. Liver of mice group (4), showing mild vacuolations in some hepatocytes with slight congestion in the central vein besides presence of large number of Von Kupfer cells, H\&E, X 400. E. Liver of mice group (5), showing focal mononuclear cell aggregation, and vacuolations of hepatocytes, H\&E, X 400. F. Liver of mice group (6), showing dilated sinusoids with mild mononuclear cell infiltration besides, mild vacuolations of hepatocytes, $H \& E, X 400$.

\section{Conclusion}

The author advice to the public uses the pomegranate molasses as protective from toxicity by silver nanoparticles toxicity.

\section{Conflict of interest}

None.

\section{References}

[1] Xie Y., Morikawa T. and Ninamiya K. (2008): Medicinal flowers. New tarazstrane type tritrepone, punicanolic acid with tumor necrosis factor-alpha inhibitory activity from the flowers of punica granatum. Chem. Pharm. Bull. 56(11): 1628-1631.

[2] Seem NP., Henning S.M. and Zhang Y. (2006): Pornegranate Juice ellagitannin metabolites are present in human plasma and some persist in urine for up to $48 \mathrm{hrs}$. J. Nutr; 136(10):2481-2485.

[3] Zarei M., Azizi M. and Bashir-Shadr Z. (2017): Elvaluation of physic-Chemical characteristics of pomegranate (Punica granatum) fruit ripening. Fruits, 66(2):121-129.

[4] Gil M.I., Tomas-Barberan F.A. and HessPierce B. (2000): Antioxidant activity of pomegranate Juice and its relationship with phenolic composition and processing. J. Agric. Food chem. 48:14821489.

[5] Petti S. and Scully C. (2009): Polyphenols, oral health and disease, Review. J. Dent., 37(6):413-423.

[6] Farber, J.L. (1994): Mechanisms of cell injury by activated oxygen species. Environ. Health Prespect. 102,17-24.

[7] Hogg, N. (1998): Free radicals disease. Semin. Reprod. Endocrinol., 16:241-288.

[8] Jayaprak N., Resing H. and Horvath R. (2017): The antioxidant activity of pomegranate punica granatum peel and seed extracts. J. Nutr., 1(1): 56-59.

[9] Bystrzejewska- Piotrowska, G. Golimows Ri-J. and Urban, P.L. (2009): Nanoparticles, their potential toxicity, waste and environmental management. Waste Management, 29:2587-2595.

[10] Khlebtsov, N. and Dykaman L. (2011): Biodistribution and toxicity of engineered gold nanoparticles; a review of in vitro and in vivo studies. Chem. Soc. Rev. 40:1647-1671.

[11] Geal M.; Peir R. and Kwon K. (2017): Cytotoxicity of silver nanoparticles. Single Rev. Toxicol. 55(2): 1-9.

[12] Monopali, M.P., Aberg, C., Salvati, A. and Dawson, K.A. (2011): Physical chemical aspects of protein corona: relevance to in vitro and in vivo biological impacts of nanoparticles. J. Am. Chem. Soc., 133(8):2525-2534.

[13] Ogawara, K.I., Yoshida, M., Higaki, K., Kimura, T., Shirashi, K., Nishikawa, M. Takakura, Y. and Hashida, M. (1999): Hepatic uptake of polystyrene microspheres in rats: Effect of particle size on intrahepatic distribution. J. Controlled Release, 59:15-22.

[14] Bancroft, T.D, Stevens, A. and Turner D.J. (1996): Theory and practice of histological technique. $4^{\text {th }}$ ed. Churchill, Living Stone, New York, London, San Francisco.

[15] Al-arifi, S., Ali, D., Al-Gurabi and Alkahtani, S. (2016): Determination of nephrotoxicity and genotoxic potential of silver nanoparticles in Swiss albino mice. Toxicol. Environ. Chemi. To Link to this article: $\quad \mathrm{http} / / \mathrm{dx}$.doi.org/10.1080 /02772248.2016-175153.

[16] Jahromy, M.H. and Kermani R.M. (2010): Chondro-protective effects of pomegranate Juice on Monoiodoactate- 
induced osteoarthritis of the knee Joint of mice Phytother. Res. 24:182-185.

[17] Henery R.J., Chiomari, N., Golub, O.J. and Berkamn, S. (1960): Revised spectrophotometric methods for the determination of glutamate oxaloacetic transferase, glutamic pyruvate transaminase and lactic acid dehydrogenase. Am. J. Clin. Path., 34:381-398.

[18] Henley, K.S. and pollard, H.M. (1955): A new method for the determination of Glutamic oxaloacetic and glutamic pyruric transaminase. J. Lab. And Clin. Med., 46:785-789.

[19] Nandi, A. and Chatterjee I.B. (1988): Assay of superoxide dismutase activity. J. Biosei., 13(3):305-315.

[20] Claiborne, A. (1985): Catalase activity. In CRC Handbook of Methods for Oxygen Radical Research, Boca Raton, ed. by R.A. Greenwood. CRC Press. 283-284.

[21] Satoh K. Serum lipid peroxide in cardiovascular disorders determined by a new colourimetric method. Clin Chem Acta. 1978;90:37-42.

[22] Paglia, D.E. and Valentine, W.N. (1967): Studies on qualitative and quantitative characterization of erythrocytes glutathione peroxidasee. J. Lab. Clin. Med., 70, 158.

[23] Tamhane, A.C. and Dunlop D.D. (2000): Statistic and data analysis from elementary to intermediate. Upper Saddle River., USA.

[24] Duncan, D.B. (1995): Multiple Range and Multiple F-test/ Biometrics. 11:1-42.

[25] Karmi M., Jeddi and Ahmadi (2008): Evaluation of the effectiveness of different levels of silver nanoparticles on bursa fabricus development and on its histopathological lesions in broiler chicks. Acta Agraria Kapos Variensis, 3(2): 353-360.

[26] Ebabe E. R., Gaillet S., Vidé J., Romaine, Lauret C. and Rugani N. (2013): Dietatary exposure to silver nanoparticles in spragwe -Dawely rats: effects on oxidative stress and inflammation. Chem. Toxicol., 60:297301.

[27] Cherghi J., Hosseini E. and Hoshmandfar R. (2013): In vivo effect of silver nanoparticles on serum ALT, AST and ALP activity in male and female mice. Adv. Environ Biol., 7(1):116-122.

[28] Lee T, Liu, M.S., Huang L.J., Lue S.I. and Lin Le. (2013): Bioenergetic failure correlotes with autophagy and apoptosis in rat live following silver nanoparticles intraperitoneal administration. Particle Fib. Toxicol. 10(40):1-13.

[29] Gatti, A.M., Monatnari S., Monari, F., Gambarelli A., Capitani F. and Parisini B. (2004): Detection of micro- and nanosized biocomparticles in the blood. J. Mater. Sci. Mater Med., 15:469-472. 


\section{الملخص العربى}

التأثير الوقائى لعصير الرمان من التسمم الكبدى لجزيئات الفضة النانونية فى ذكور الجرذان البيضاء البالغة

$$
\begin{aligned}
& \text { أمبرة عبد الستار سلام ، منى محي أحمد ، على حيدر أبو حديد ومجدى فكرى أبو الفتوح }
\end{aligned}
$$

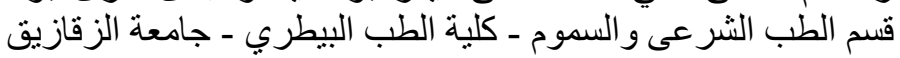

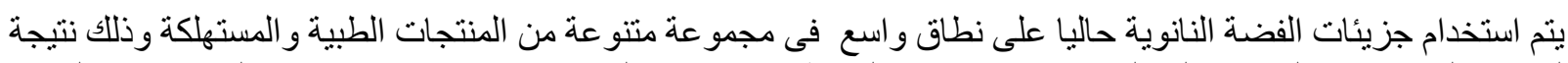

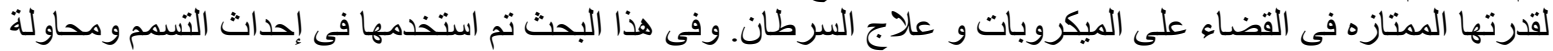

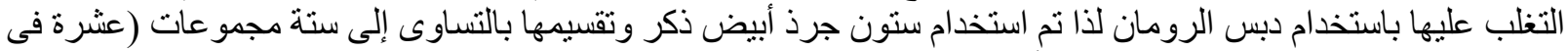

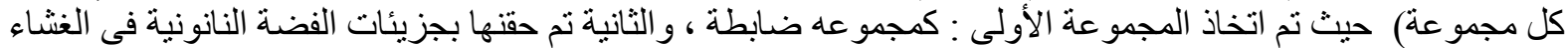

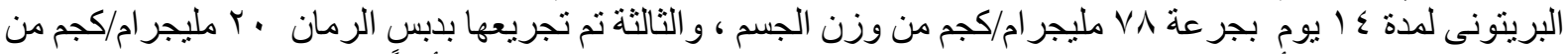

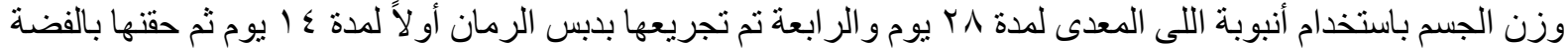

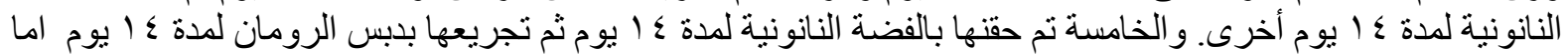

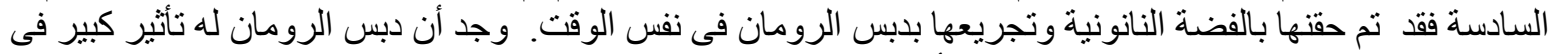

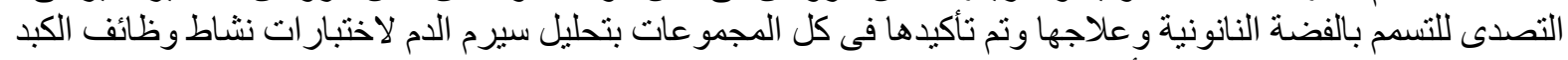

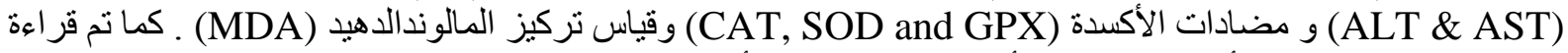
وتحليل الهستوباثولوجى لأنسجة الكبد وجد أن دبس الرومان له تأثير كبير فى اعادة وتجديد الخلايا الكبدية وخلايا كوفر بعد استخدامه فى التسمم بالفضة النانونية 